\title{
ГРАЖДАНСКОЕ ПРАВОСОЗНАНИЕ В ОБЩЕСТВЕННО-ПОЛИТИЧЕСКИХ ПРАКТИКАХ И ЦЕННОСТНЫХ УСТАНОВКАХ РОССИЯН
}

\begin{abstract}
Аннотация: Статья посвящена изучению проблемыгражданского правосознания вобщественно-политическихпрактикахи ценностныхустановкахроссиян. Гражданскоеправосознаниерассматриваетсякакнеобходимыйэлемент функиионирования гражданского общества иправовогогосударства, признающего иреализующего права, свободы иинтересы человека игражданина в качестве выссией ценности. Особое вниманиеуделено анализу связигражданского правосознания суровнем сочиального иинституционального доверия, общественного и политического участия, ценностных ориентацийиполитическихустановок всовременном российском обществе. Анализ проблемы учитывает основные положения теориимодернизации относительно трансформации соииально-политической субъектности общества игражданина, позволяюшие конщептуализировать связь гражданского правосознания собщественно-политическимипрактикамииценностнымиориентациямироссиян. Сделан вывод о существовании глубокого разрыва между традиияями общественно-политического участия, носящими преимущественно коллективистский, конвенциональный, институциональньйхарактер, инизкимуровнемдоверия сложившимсявпостсоветский период публичным институтам, что во многом обусловливает противоречивость гражданского правосознания, ценностных установок и практик гражданского участия в современном российском обществе.
\end{abstract}

Ключевые слова: Гражданское правосознание, гражданское участие, соииально-политические практики, ценностные установки, российское общество, гражданское общество, институты, власть, государство, гражадне.

Abstract: This article is dedicated to the study of the issue of civil legal awareness within the social-political practices and values of the Russian citizens. Civil legal awareness is being viewed as a necessary element of the functioning of the civil society and legal state that recognizes the rights, liberties, and interests of human and citizen as the highest values. A special attention is given to the analysis of the link between civil legal awareness and the level of social and institutional trust, public and political participation, value orientation, and political alignments in the modern Russian society. Analysis of the issue takes into account the key positions of the theory of modernization with regards to the transformation of the socio-political subjectivity of the society and the citizen that allow the conceptualization of the link between civil legal awareness and the socio-political practices and value orientations of the Russian citizens. The authormakes a conclusion on the existence of a deep divide between the traditions of the socio-political participation that carry a mostly collectivistic, conventional, and institutional character and a low level of trust that has formed in the post-Soviet period by the public institution, which in many ways substantiates the divergence in the civil legal awareness, values, and practices of civil participation in the modern Russian society.

Keywords: Civil legal awareness, Civil participation, Socio-political practice, Values, Russian society, Civil society, Institutions, Authority, Government, Citizens.

современном мире гражданское правосознание является необходимым элементом функционирования гражданского общества и правового государства, признающего и реализующего права, свободы и интересы человека и гражданина в качестве высшей ценности. Гражданское правосознание представляет собой совокупность знаний, взглядов, идей, отражающих оценку объективной действительности с точки зрения реализации таких важнейших принципов как верховенство права, взаимная ответственность гражданина и государства, равноправие граждан не- зависимо от религиозной, национальной принадлежности, уважительное отношение к языку, традициям и обычаям других народов, патриотизм. Сегодня в связи с обострением социальных и политических конфликтов, как за рубежом, так и в России, реализация каждого из этих принципов, отражающих содержание гражданского правосознания, является задачей первостепенной важности для общества и государства.

Понятие «гражданское правосознание» производно от понятия «правосознание» и «сознание», которое можно определить как отличительное свойство 
DOI: $10.7256 / 1811-9018.2015 .2 .12138$

При цитировании этой статьи сноска на доі обязательна

\section{Право и политика 2 (182) 2015}

человека, позволяющее придавать его деятельности целенаправленный, предсказуемый и планируемый характер. Правосознание представляет собой форму общественного сознания, позволяющую не только констатировать, но и оптимизировать процессы правотворчества, правоприменения и реализации права, то есть отличается как правоустановленностью, так и возможностью оказывать непосредственное влияние на процессы создания, применения и реализации соответствующих правовых норм. В данном смысле гражданское правосознание подразумевает возможность отдельных граждан и их объединений выдвигать, обсуждать и реализовывать в практических действиях новые взгляды и подходы к решению общезначимых социальных проблем, инициировать и требовать соблюдения и защиты свобод и прав граждан государственными и общественными институтами.

Проявление гражданского правосознания в каждом обществе имеет свою специфику, которая обусловлена совокупностью институциональных и социокультурных факторов, социально-политической динамикой, сочетанием глобального и национального контекста. Гражданское правосознание в полной мере реализуется в представлениях граждан о своих базовых правах и свободах и возможностях их реализации в различных формах политического и общественного участия. Особое значение гражданское правосознание имеет в условиях обострения социальных противоречий, политических конфликтов и кризисов. Гражданское правосознание является основой общественного саморегулирования, способствующего нахождению решений социальных и политических конфликтов в рамках существующих правовых норм, что особенно актуально для российского общества, пронизанного различными противоречиями - социальными, культурными, территориальными, этническими, конфессиональными и др.

Особенно актуальной проблема гражданского правосознания видится применительно к сфере взаимодействия государства и общества. Гражданское общество выдвигает на авансцену социально активную позицию личности, инициативу и самодисциплину, самодеятельность и предприимчивость, определенную меру требовательности и ответственности, как к себе самому, так и к существующим политическим и общественным институтам. При этом такое поведение пронизывает всю структуру общественных отношений, включая социальное и институциональное доверие, общественное и политическое участие, ценностные ориентации и политические установки. В данном плане важным представляется теоретический и эмпирический анализ общественно-политических практик и установок россиян на современном этапе.

Отмечая низкий уровень гражданской активности в современной России, исследователи часто объясняют этот факт отсутствием демократических традиций, неразвитостью гражданского общества, глубоко укоренившимися патерналистскими настроениями, ограничениями со стороны государства. И даже всплеск гражданской активности в 2011 - 2012 гг. не дал достаточно серьезных оснований для оптимизма в данном вопросе. Большая часть россиян по-прежнему не готова воспринимать общество в его автономности от политических институтов как самодеятельную и самоуправляемую сущность, исходную для всех других функций и образований, принципиально первичную структуру, в которой реализуются основные жизненные интересы человека. Между тем, очевидно, что гражданские протесты начала 2010-х гг. не были случайным событием. В российском публичном пространстве появились новые акторы, новые формы и практики коллективной самоорганизации, новые способы социально-политической коммуникации. Оформился запрос на политическую модернизацию, смыслом которой объявлялось становление предельно открытой, гибкой и внутренне сложной политической системы, адекватной динамичной, подвижной, прозрачной и многомерной социальной структуре, отвечающей культуре свободных, обеспеченных, критически мыслящих, уверенных в себе людей ${ }^{1}$.

Причиной роста гражданской активности многие исследователи связывают с глобальными социально-экономическими, политическими, культурными и технологическими изменения, получившими свое осмысление в рамках теории модернизации. Центральным пунктом теории модернизации является то, что экономическое развитие обусловливает последовательные и до некоторой степени предсказуемые изменения в культурной, социальной и политической жизни, а именно переход от абсолютных норм и ценностей к ценностям растущей рациональности, толерантности, доверия и участия ${ }^{2}$. Гражданское участие при этом воспринимается как необходимое условие модернизации общества. Совершенствование публич-

\footnotetext{
${ }^{1}$ Россия, вперед! Статья Дмитрия Медведева. 10.09.2009 г. [Электронный ресурс]. [Офиц. сайт Президента PФ]. URL:http://kremlin. $\mathrm{ru} /$ transcripts/5413 (дата обращения 20.03.2014 г.).

2 Inglehart R., Baker W.E. Modernization, cultural change, and the persistence of traditional values // American sociological review. 2000. Vol. 65. February. P.19-21.
} 
ных институтов и публичной политики происходит при непосредственном участии граждан и учете их мнений в процессе выработки и принятии социально значимых решений. В итоге публичные институты рассматриваются не как «спущенные сверху и предзаданные» сущности, а как непосредственный результат социального творчества масс.

И все же основным субъектом модернизации в нашей стране по-прежнему остается государство. В глазах россиян именно государство как выразитель общих интересов должно, принимая во внимание интересы различных субъектов, на базе общественного консенсуса проводить политику, направленную на благо народа как единой общности ${ }^{3}$. Причиной тому является не только культурные и институциональные традиции. Речь также идет о противоречии глобального процесса модернизации: между объединением людей поверх географических границ, государств, социальных классов, идеологий, религий, национальностей и этносов и погружением человечества в водоворот постоянной дезинтеграции и обновления, борьбы и конкуренции, двусмысленности и неопределенности ${ }^{4}$.

С одной стороны, происходит повышение уровня гражданской активности как следствии роста индивидуальных возможностей для самореализации и самовыражения в различных сферах жизни, в том числе в сфере общественной деятельности. Социально-экономическая модернизация ведет к ослаблению внешних ограничений свободы выбора, увеличивая материальные, когнитивные и социальные ресурсы личности 5 . Это приводит к усилению акцента на ценностях самовыражения, а оно в свою очередь, ведет к нарастанию в обществе требований в пользу гражданских и политических свобод, способствуя формированию и укреплению институтов демократии. С другой стороны, распространение индивидуалистских ценностей, напротив, ведет к росту социального и институционального недоверия, снижению социального капитала, что подрывает активное гражданское участие, которое сильная демократия требует от своих граждан. Политические институты, призванные выступать посредниками и выразителями

\footnotetext{
${ }^{3}$ Куда ведет кризис культуры? Опыт междисциплинарных диалогов / Под общ. ред. И.М. Клямкина. М.: Новое литературное обозрение, 2011. С.308-309.

${ }^{4}$ Berman M. All that is Solid Melts Into Air: The Experience of Modernity. NY: Simon and Schuster, 1983. P.15.

${ }^{5}$ Инглхарт Р., Вельцель К. Модернизация, культурные изменения и демократия: Последовательность человеческого развития. М.: Новое издательство, 2011. С.12.
}

интересов различных социальных групп, постепенно утрачивают связь с обществом, превращаясь в инструменты обслуживания частных и корпоративных интересов. По причине дисфункциональности современных политических институтов социальная энергия перенаправляется от конвенциональной политики в менее формальные, более добровольные и эффективные каналы ${ }^{6}$, действуя порой разрушительно. Таким образом, две тенденции - расширение свободы выбора и растущее недоверие политическим институтам - создают общие предпосылки для активизации социального взаимодействия на низовом уровне, вне формальных институциональных рамок.

Выделенные тенденции не существуют изолированно друг от друга, как не существуют отдельно друг от друга. В своем взаимодействии они создают различные - смешанные - контексты, что не позволяет однозначно подходить к характеристике гражданских активистов исключительно как носителей новой, более передовой, социокультурной субъектности и тем более - категорически противопоставлять их носителям традиционной субъектности. По крайней мере, нет достаточных оснований утверждать, что большая часть российского общества - бедная, малообразованная, иммобильная - живет под знаком «не было бы хуже» и поэтому является сторонником идеи стабильности, а меньшая часть - обеспеченная, образованная, амбициозная - стремится к успеху и социальному прогрессу. Существует достаточно большая промежуточная группа, которая имеет смешанные ценностные ориентиры. Об этом говорят результаты многих социологических исследований.

Об этом говорит и вывод Г. Алмонда относительно трех типов политической культуры - парохиальной, подданической и партисипаторной, все вместе образующих культуру гражданственности 7 . Вывод Г. Алмонда особенно важен для понимания того, что гражданская культура складывается из представлений, норм и поведений всех слоев общества, а не избранной его части. Гражданская культура является объединяющим, а не разъединяющим началом, и в данном смысле гражданская культура - это не нормативная категория, а объективно существующий феномен - социально-политическая система, интернализированная в суждениях, поведенческих практиках и чувствах граждан.

\footnotetext{
${ }^{6}$ Putnam R.D. Bowling Alone: The Collapse and Revival of American Community. NY: Simon \& Schuster, 2000. P.47.

${ }^{7}$ Almond G.A., Sidney V. The civic culture. Political attitudes and democracy in five nations. Princeton: Princeton University Press, 1963. P.18-19.
} 
DOI: $10.7256 / 1811-9018.2015 .2 .12138$

При цитировании этой статьи сноска на dоі обязательна

\section{Право и политика 2 (182) 2015}

Важен, на наш взгляд, и вывод Г. Алмонда о двух противоречиях гражданской культуры: 1) между высокой оценкой потенциального и низким уровнем реального влияния граждан на политические решения; 2) между высокой оценкой потенциального и низким уровнем реального участия в общественно-политической жизни. По мнению Г. Алмонда, эти два противоречия помогают понять, каким образом в странах устойчивой демократии обеспечивается баланс между стабильностью и развитием. С одной стороны, пассивность обычного гражданина в политической сфере помогает обеспечить правящие элиты властью в той мере, которая необходима для эффективного решения проблем. С другой стороны, роль гражданина, как активного и влиятельного фактора, обеспечивающего ответственностью элит, поддерживается благодаря его приверженности нормам активного гражданства и его убежденностью, что он может быть влиятельным политическим актором.

Таким образом, гражданин в стране с гражданской политической культурой является потенциально активным. Он не выступает как постоянный участник политического процесса, редко активен в политических группах, но при этом обладает резервом потенциального влияния. То есть в случае необходимости гражданин может мобилизовать свое социальное окружение в политических целях. Гражданин, живущий в такой стране, в большей степени склонен поддерживать на высоком и постоянном уровне политические связи, входить в какую-либо организацию и участвовать в неформальных политических дискуссиях. Эти виды деятельности сами по себе не указывают на активное участие в процессе принятия политических решений, но делают такое участие более вероятным. На наш взгляд, выводы Г. Алмонда помогают понять ситуацию, сложившуюся на текущий момент в российском обществе. Социальная стабильность - это не только баланс интересов, но также результат соотношения потенциального и реального участия и влияния различных групп и слоев. Но российская действительность имеет и свою специфику, о чем говорят результаты проведенного исследования 8 .

В современном российском обществе образовалась сложная и противоречивая нормативно-ценностная структура, при которой ценности, нормы и установки различной, порой противоположной, идейной направленности специфическим образом «распределены» в социальном пространстве и «уравновешивают» друг друга, создавая необходимые предпосылки если не для социальной сплоченности, то социального компромисса, как минимум.

Прежде всего, обращает на себя внимание различие между носителями традиционалистских и модернистских взглядов. Основными факторами при этом являются уровень материального положения, уровень образования, возраст, тип поселения, в котором проживают респонденты. Так, граждане с более высоким уровнем материального положения демонстрируют бо́льшую приверженность ценностям личной независимости, самовыражения, инициативы, конкуренции и готовности к переменам (см. табл. 1). Аналогичный выбор делают также респонденты более молодого возраста, с более высоким уровнем образования и проживающие в мегаполисах и крупных городах, хотя в каждом случае, безусловно, действуют разные социальные механизмы и факторы. В то же время, как показывают данные таблицы, для всех слоев населения практически одинаково важной оказывается возможность гражданского участия, рассматриваемого как активная борьба за свои интересы и права.

Таблица 1

С каким из нижеперечисленных суждений Вы в большей степени согласны? \%

\begin{tabular}{|c|c|c|c|}
\hline Материальное положение & $\begin{array}{c}\text { хорошее, очень } \\
\text { хорошее }\end{array}$ & среднее & $\begin{array}{c}\text { плохое, очень } \\
\text { плохое }\end{array}$ \\
\hline \multicolumn{4}{|c|}{ Финансовая независимость } \\
\hline $\begin{array}{l}\text { Могу обеспечить себя и свою семью и не нуждаюсь в поддержке } \\
\text { со стороны }\end{array}$ & 64 & 45 & 22 \\
\hline Без поддержки со стороны государства мне и моей семье не выжить & 36 & 54 & 78 \\
\hline \multicolumn{4}{|l|}{ Перемень } \\
\hline Мне нравятся перемены & 71 & 51 & 34 \\
\hline Все перемены к худшему & 28 & 48 & 65 \\
\hline
\end{tabular}

${ }^{8}$ Анализ сделан по результатам социологического опроса, проведенного Институтом социологии РАН в марте 2014 г. 
DOI: $10.7256 / 1811-9018.2015 .2 .12138$

При цитировании этой статьи сноска на ооі обязательна

Трансформация правовых и политических систем

Человек - кузнец своего счастья

\section{Личные усилия}

Жизнь человека в большей степени зависит от внешних обстоятельств

Конкуренция

Конкуренция - это хорошо, она побуждает человека напряженно

трудиться, выдвигать новые идеи

$70 \quad 53 \quad 3$

$30 \quad 47$

Конкуренция вредна, она усиливает в человеке его

отрицательные черты

79

$79 \quad 57$

$21 \quad \mathbf{4 3}$

\section{Самовыражение}

Выделяться среди других лучше, чем жить как все

Жить как все лучше, чем выделяться среди других

\section{Инициатива}

Главное - это инициатива, предприимчивость, поиск нового, даже если оказываешься в меньшинстве

Главное - это уважение сложившихся обычаев, традиций

$$
\text { Гражданское участие }
$$

Нужно активно бороться за свои интересы и права

43

43

Нужно уметь приспосабливаться к реальности, а не тратить силы на борьбу с ней

$57 \quad 43 \quad 30$

$43 \quad 56 \quad \mathbf{7 0}$

Между тем, как показывают результаты опроса, уровень гражданской активности в нашей стране чрезвычайно низок. Две трети респондентов отметили, что в течение последних двухлет онинепринималиучастия в деятельностикаких-либо общественных организаций, объединений и сообществ. Чаще всего респонденты оказывались участниками интернет-сообществ (10\%), ассоциаций соседей или товариществ собственников жилья (9\%), профсоюзов (8\%), благотворительных (6\%), студенческих (5\%) или ветеранских (3\%) организаций.

Среди возможностей, которые привлекают в общественно-политической деятельности, россияне в первую очередь отмечают возможность защиты своих прав и прав своих близких и общение с людьми с теми же ценностя-

ми и убеждениями (см. рис. 1). В целом, можно сказать, что в структуре возможностей коллективные ценности, очевидно, пользуются большей поддержкой, нежели ценности самовыражения и индивидуального роста. Все это говорит о том, что увеличение материальных, когнитивных и социальных ресурсов личности, на которые обращал внимание Р. Инглхарт, само по себе является недостаточным фактором роста гражданской активности. Не менее важным фактором является структура социально-политических возможностей, существующая в обществе в данный момент, которая осознается гражданами одновременно как условие и перспектива своего участия в общественно-политической деятельности.

Рисунок 1

Какие возможности привлекают Вас в общественно-политической деятельности, \%

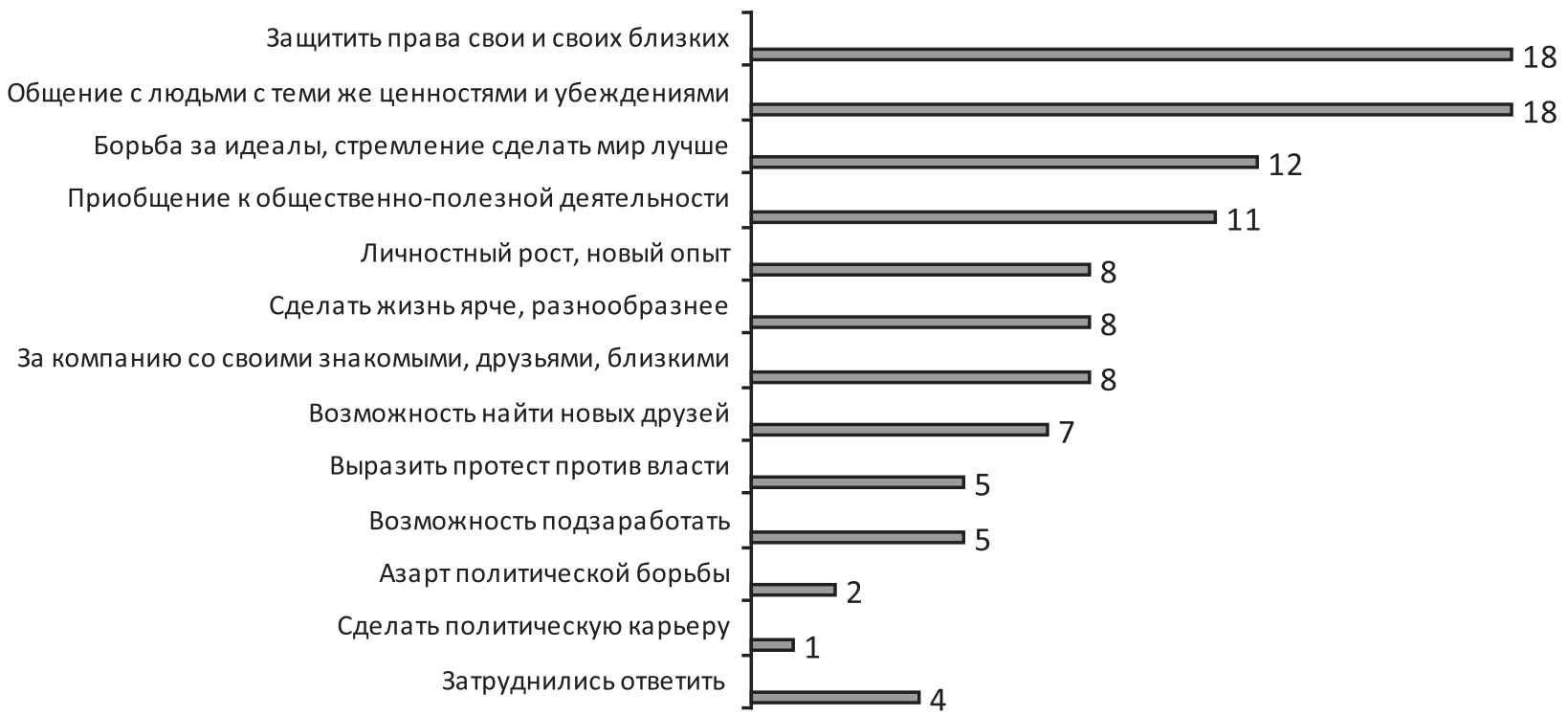


DOI: $10.7256 / 1811-9018.2015 .2 .12138$

При цитировании этой статьи сноска на dоі обязательна

\section{Право и политика 2 (182) 2015}

При рассмотрении причин, по которым подавляющая часть россиян не участвуют в общественно-политической деятельности, в первую очередь обращает на себя внимание неверие граждан в то, что их участие принесет какую-то общественную пользу (см. рис. 2). как у Вас, но разной формы организации - официально зарегистрированной и неформальной - Вы бы поддержали?» 25\% респондентов готовы присоединиться к официально зарегистрированной организации и только 5\% - к неформальной. При этом

Рисунок 2

Если Вы не принимали участия в общественной и политической жизни, то почему? \%

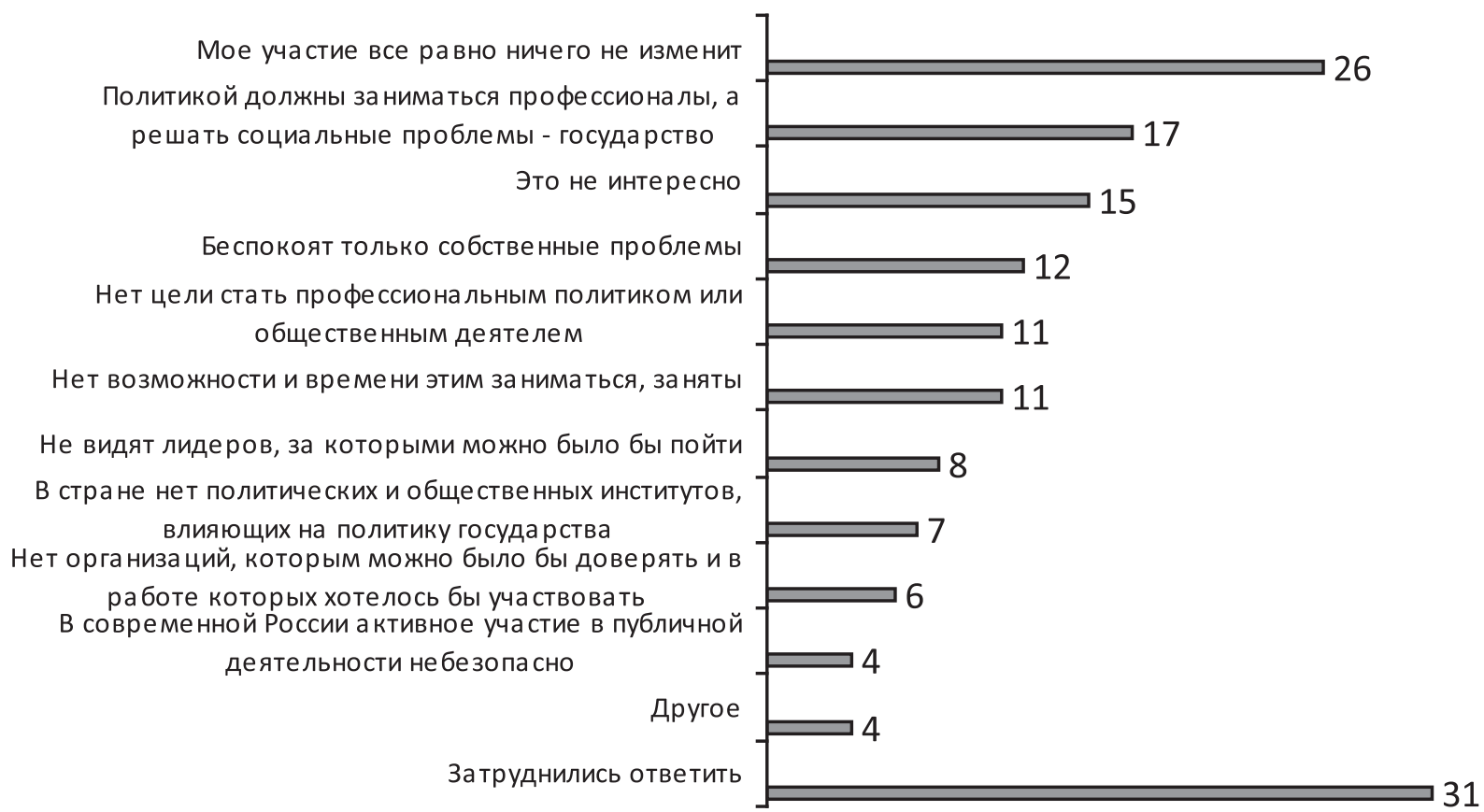

В структуре причин, по которым граждане отказываются участвовать в общественно-политической жизни, также можно выделить несколько блоков. Наиболее распространенным мотивом является неверие, что это что-то изменит, т.е. сомнение в эффективности собственного участия. Меньшую роль играют причины индивидуального характера - отсутствие интереса, времени или желания. Наконец, низкий уровень институционального и социального доверия, т.е. отсутствие в стране публичных институтов, организаций и лидеров, которым можно было бы доверять, также является мотивом для отказа от участия в общественно-политической деятельности.

Низкий уровень институционального доверия самым негативным образом сказывается на уровне гражданской активности в нашей стране еще и потому, что среди россиян достаточно сильны традиции именно организованного участия и слабо развиты формы коллективной самоорганизации. Об этом, в частности, говорят ответы на вопрос «Какое объединение людей с такими же взглядами и убеждениями,

35\% опрошенных оказались не готовыми присоединиться к какой-либо организации даже, несмотря на сходство взглядов и убеждений. Таким образом, существует достаточно серьезное противоречие, ограничивающее рост гражданской активности среди россиян. С одной стороны, традиции общественно-политической деятельности в нашей стране предполагают преимущественно организованные, формализованные виды участия, с другой стороны, уровень доверия к ним и готовность населения принимать в них участие становятся все ниже, но в то же время пока не сложилось устойчивое доверие и общественным структурам.

Речь идет, прежде всего, о тех политических и общественных организациях, чьи функции непосредственно связаны с представительством и защитой прав и интересов различных социальных групп и слоев. Как показывают результаты исследования, именно данные структуры в настоящее время испытывают крайний дефицит доверия со стороны граждан, причем независимо от уровня их материального положения (см. рис. 3). 
Уровень доверия государственным и общественным институтам (в зависимости от уровня материального положения), \%
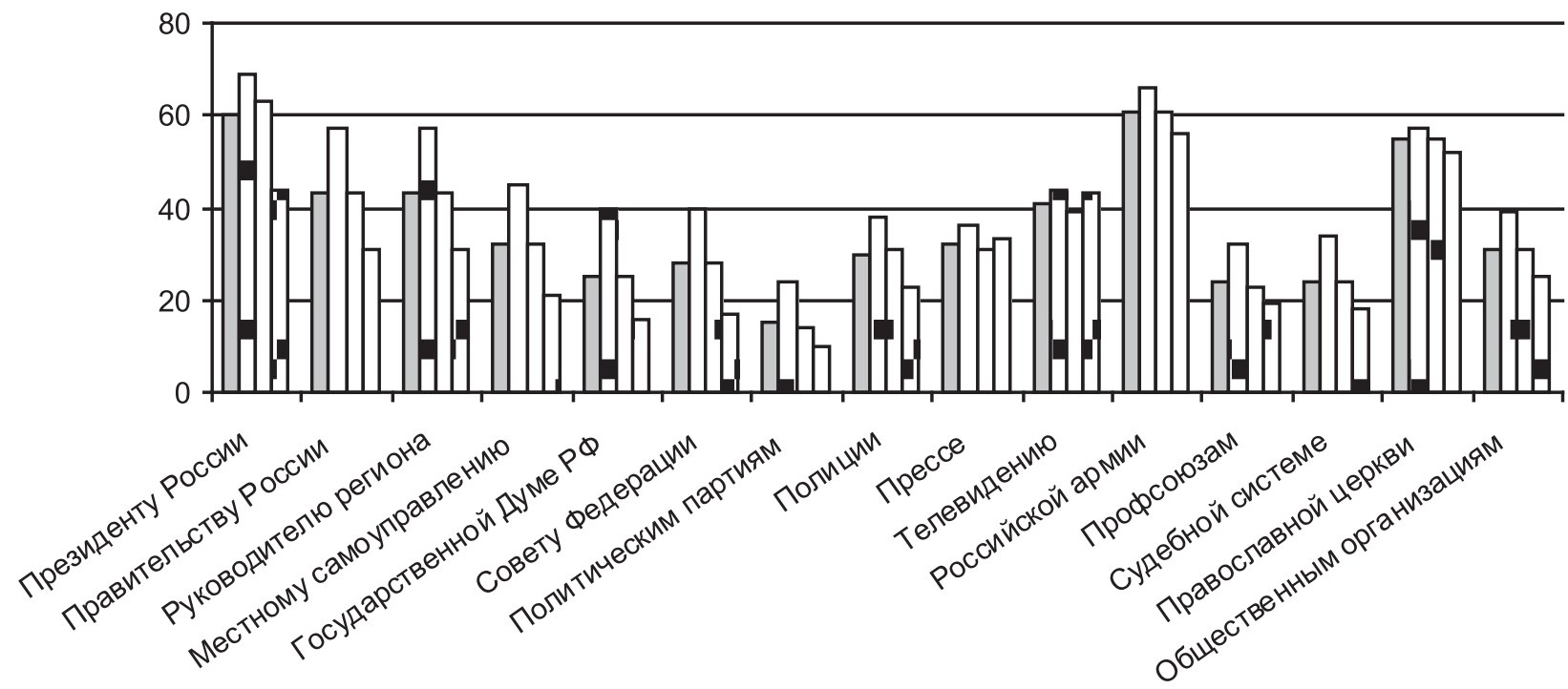

$\square$ Среди в сех опрошенных $\square$ хорошее, очень хорошее $\square$ среднее $\square$ плохое, очень плохое

Обращает на себя внимание «топ-лист» институтов, к которым в целом граждане испытывают наибольший уровень доверия: президент РФ (60\%), армия (60\%) и православная церковь $(55 \%)$. Можно сказать, что в сознании граждан сложилась и определенная «вертикаль доверия» аналогично «вертикали власти»: президент РФ (60\%), правительству России (43\%), руководителю региона (43\%), органам местного самоуправления (32\%). Наконец, стоит отметить крайне низкий уровень доверия институтам, призванным представлять и защищать интересы граждан в их отношениях с государством - Государственной Думе РФ (25\%), политическим партиям (15\%), судебной системе и профсоюзам (24\%), а также общественным и правозащитным организациям (31\%).

Небольшие различия существуют в разрезе материального положения респондентов. Респонденты с высоким уровнем материального благополучия демонстрируют самый высокий уровень поддержки и доверия государственным и общественным институтам. С одной стороны, это говорит о том, что чем выше уровень материального и финансового благополучия, тем увереннее чувствуют себя граждане в отношении с государственными и общественными структурами. Люди экстериоризируют свои ощущения и переживания на отношения с другими людьми и общество в целом. С другой стороны, это говорит о сути существующего в современной России социально-экономического и политического порядка. Видимо, пока рано говорить о том, что среди так называемого российского среднего класса, в данном случае без учета его специфики, зреют какие-то новые более перспективные и передовые формы и модели его взаимоотношений с властью. Скорее, можно говорить, что российский средний класс достаточно прочно встроен в существующую систему производства и распределения, и это дает ему пока больше преференций, нежели убытков. Следовательно, протестные выступления «сетевых хомячков» и «рассерженных горожан» трудно назвать осознанным политическим действием, что подтверждается отсутствием у лидеров гражданских акций, даже наиболее резонансных из них, какой-либо стройной системы социально-политических взглядов и основанных на ней конкретных целей и задач, способных привлечь широкие массы.

Если рассматривать политическую и общественную деятельность как разные формы гражданской активности, то обращает на себя внимание минимизация сферы политического участия, фактическое сведение ее к участию в выборах в качестве избирателя. На это указали $41 \%$ респондентов. При этом в работе органов местного самоуправления заинтересованы всего $6 \%$ респондентов, а в деятельности политических партий и того меньше $-5 \%$. 
DOI: $10.7256 / 1811-9018.2015 .2 .12138$

При цитировании этой статьи сноска на dоі обязательна

\section{Право и политика $2(182) \cdot 2015$}

В то же время сфера общественной активности представлена большим числом и разнообразием направлений - от творческих до благотворительных (см. рис. 4). должны заниматься общественные организации и благотворительные фонды, 34\% - местные власти, 24\% церковь, $14 \%$ - федеральные органы власти ${ }^{9}$. По мнению россиян, мероприятия, организованные федеральными

Рисунок 4

Как Вы относитесь к деятельности различных общественных объединений? \%

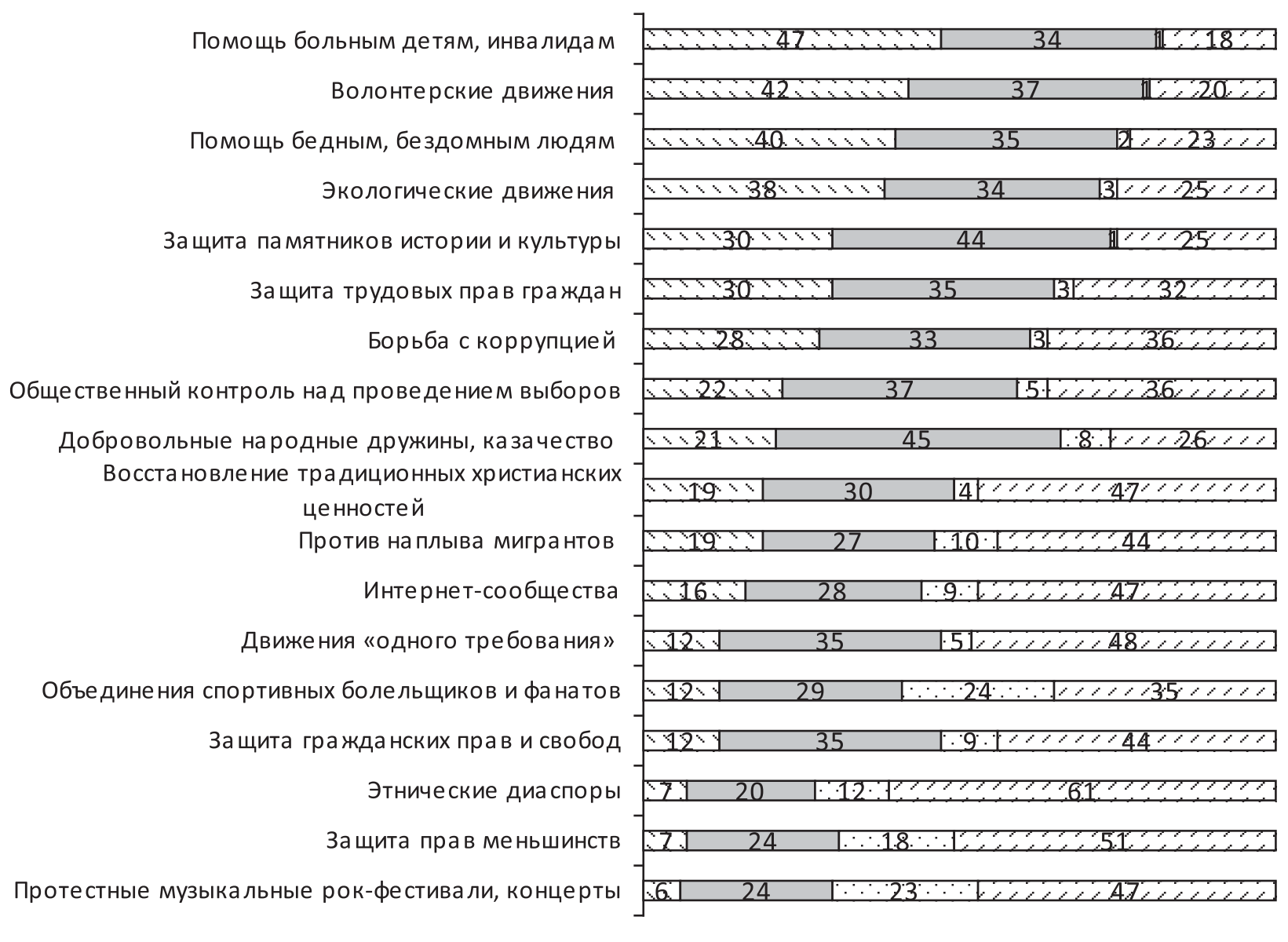

๑ симпатией, готов поддержать

$\square$ Негативно

Как видно из рисунка, наибольшей симпатией и поддержкой среди россиян пользуются благотворительные и волонтерские движения и организации, цель которых заключается в оказании конкретной помощи нуждающимся людям, прежде всего, детям, инвалидам и попавшим в чрезвычайные ситуации гражданам. Пожалуй, наиболее ярким примером тому стала организация гуманитарной помощи во время масштабных лесных пожаров 2010 г. Показательными оказались и представления россиян о том, кто должен организовывать сбор и распределение гуманитарной помощи. По данным Левада-Центра, 50\% россиян считали, что этим
С интересом, но поддерживать не готов

$\square$ Ничего о них не знаю

органами власти, являются мало эффективными, когда речь о проблемах и судьбах отдельных людей. Гораздо лучше с подобными ситуациями справляются именно общественные организации и местные власти.

Стоит также отметить, что в числе значимых направлений общественной деятельности важное место занимают проблемы охраны окружающей

\footnotetext{
${ }^{9}$ См.: Проблемы лесных пожаров 2010 года. 28.09.2010. [Электронный ресурс]. [Офиц. сайт Аналитического центра Ю.Левады «Левада-Центр»]. URL:http://www.levada.ru/28-09-2010/problemylesnykh-pozharov-2010-goda (дата обращения 20.04.2014).
} 
среды, культурного и исторического наследия. Таким образом, общественное участие в глазах россиян оказывается важным в случае возможности объединения достаточно большого числа граждан и оказания конкретной помощи реально нуждающимся людям. Напротив, наименьшей поддержкой и симпатией пользуются движения, направленные на защиту интересов и прав отдельных категорий граждан, опосредованных какой-то нормативно-правовой ситуацией. Речь идет, например, об ущемлении прав отдельных социальных меньшинств или этнических диаспор. При отсутствии готовности поддержать россияне, тем не менее, проявляют значительный интерес к таким видам общественной деятельности, как вестны в обществе его деятельность, цели, задачи. Поэтому можно говорить о потенциале развития того или иного движения с учетом роста доступности соответствующей информации.

Говоря о проблеме ограничения сферы политического участия до пределов участия в голосовании в качестве избирателя, нельзя не отметить фактическое отсутствие политической и партийной конкуренции, что еще больше снижает значение политической сферы в глазах россиян. Если в составе Государственной Думы Российской Федерации граждане готовы видеть представителей разных политических партий, то когда речь заходит о выборе конкретной партии, то партийное разнообразие резко снижается (см. рис. 5).

Рисунок 5

По Вашему мнению, какие партии, на Ваш взгляд, должны быть представлены в составе будущей Государственной Думы РФ, и за какую из них Вы бы проголосовали, если бы выборы состоялись в ближайшее воскресенье? \%

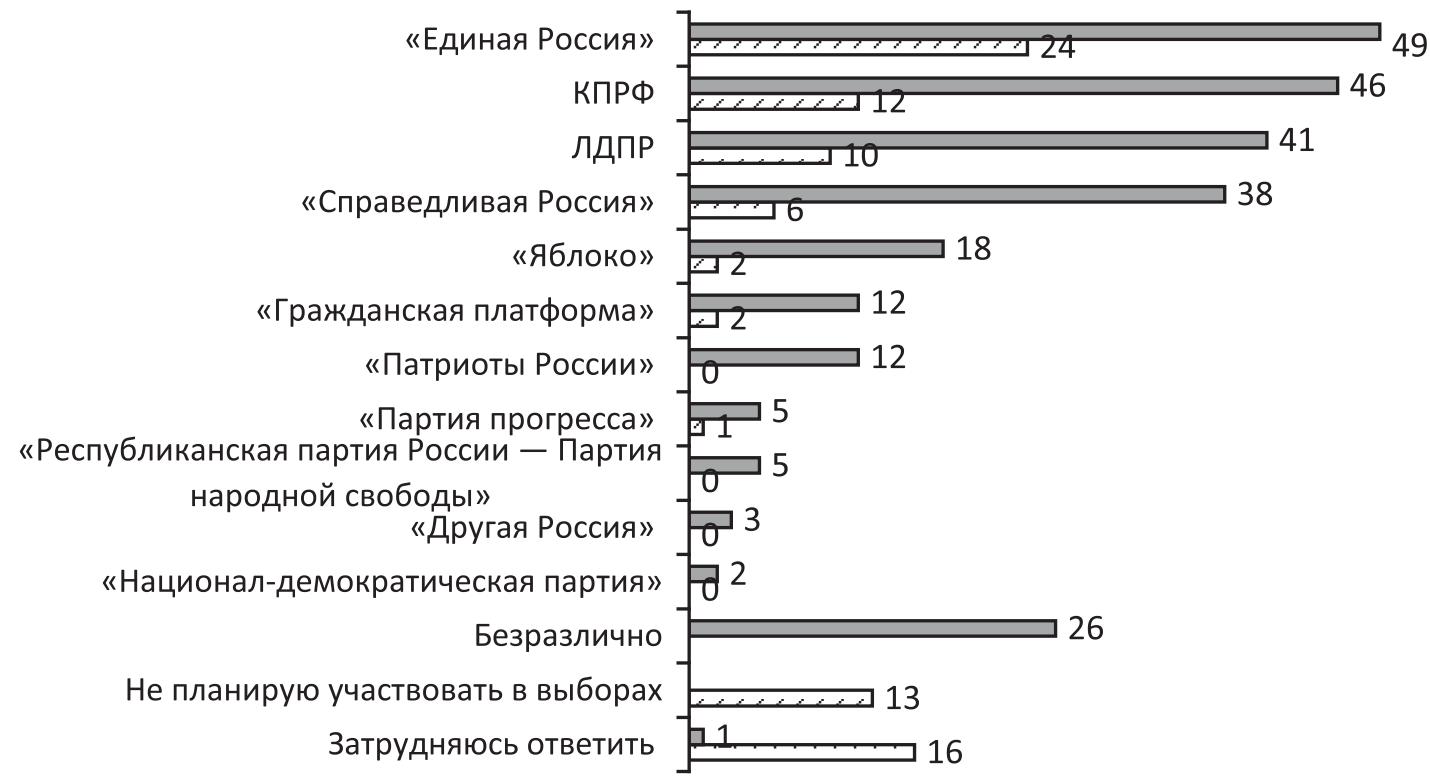

๑За какую партию бы Вы проголосовали осуществление контроля над проведением выборов, добровольные народные дружины, движения «одного требования», защита трудовых прав и гражданских прав и свобод, борьба с коррупцией. В связи с этим можно предположить, что по мере роста правовой культуры и правосознания россиян уровень поддержки данных направлений общественной деятельности также будет увеличиваться. Также можно отметить, что уровень симпатии и поддержки конкретного движения во многом зависит от того, насколько из-
Какие партии должны быть представлены в ГД

Как показывают данные диаграммы, выражение симпатии и готовность лично принять участие в общественно-политической деятельности существенно различаются. Отчасти это подтверждает вывод Г. Алмонда о том, что обычный гражданин редко активен в политических группах, но при этом обладает резервом потенциальной влиятельности и мобилизации своего социального окружения в политических целях. Чем выше уровень общей поддержки политической партии, тем выше готовность ее сторонников проголосовать за 
DOI: $10.7256 / 1811-9018.2015 .2 .12138$

При цитировании этой статьи сноска на dоі обязательна

\section{Право и политика 2 (182) 2015}

нее на выборах, и наоборот, снижение уровня общей поддержки ведет к резкому снижению электоральной поддержки. Так, на примере только парламентских партий мы видим, что в случае «Единой России» данное соотношение составляет 1:2, КПРФ и ЛДПР - примерно 1:4, а в случае «Справедливой России»- примерно 1:6. В случае политических партий, не представленных в власти, когда решение социально значимых задач россияне предпочитают видеть «сверху вниз», а не наоборот, начиная с низовой общественной самоорганизации или местного самоуправления. С этим связана и сложившаяся в представлении россиян структура возможностей представлять и отстаивать свои интересы в публичном пространстве (см. рис.6).

\section{Рисунок 6 \\ Как Вы думаете, есть ли у российских граждан сегодня возможность ...\%}

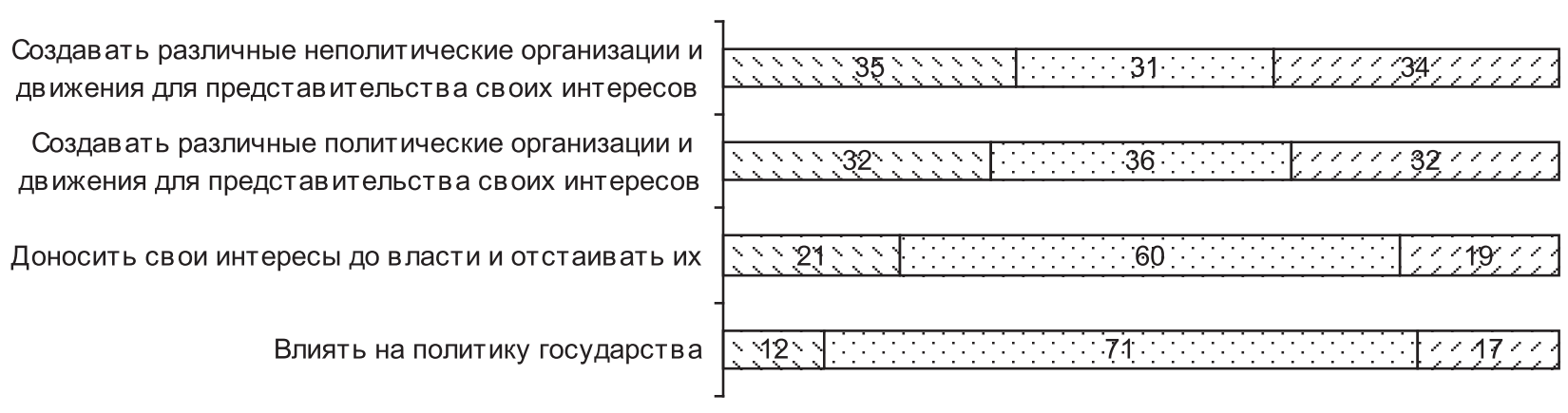

口 Есть такая возможность $\square$ Нет такой возможности $\square$ Затруднились ответить

парламенте и при этом имеющих ярко выраженную оппозиционную идеологию, разрыв между общей и электоральной поддержкой становится еще больше. К ним относятся, в том числе и националистические партии, деятельность которых с одной стороны, отражает присутствующие в обществе настроения и интересы, но выражение личной готовности нести ответственность за их деятельность в масштабе страны у граждан фактически отсутствует.

Таким образом, сравнение представлений россиян о различных формах общественно-политической активности свидетельствует о достаточно существенном противоречии между реальным и потенциальным участием. Причиной тому является глубокий разрыв между традициями общественно-политического участия, носящими преимущественно коллективистский, конвенциональный, институциональный характер, и низким уровнем доверия публичным институтам, сложившимся в современном российском обществе. Речь идет, прежде всего, об институтах, призванных выражать, представлять и инкорпорировать интересы различных групп граждан в публичной политике. Недоверие представительским институтам обусловливает стремление граждан связывать свои интересы с деятельностью исполнительной власти. В известной степени можно говорить о складывании своеобразной вертикали доверия по аналогии с вертикалью
Данные диаграммы с очевидностью показывают, что, несмотря на существующие возможности создавать различные политические и общественные организации для представительства своих интересов, это все равно не решает проблему отстаивании своих интересов в отношениях с властью, и практически нет никакой возможности повлиять на процесс принятия ею каких-либо решений. В целом можно сказать, что сложилась своеобразная пирамида, воплощающая собой специфику социально-политического участия в нашей стране. В рамках закона граждане могут создавать самые различные общественные объединения и организации для выражения и защиты своих прав и интересов, но они не могут конкурировать с государственными структурами и их деятельность оказывается не достаточно эффективной, по крайней мере, с точки зрения соотношения произведенных затрат и полученных результатов. Поэтому гражданская активность, действительно, часто носит характер борьбы, а не сотрудничества с государственными институтами. По крайне мере, об этом говорят акции, направленные на защиту Химкинского леса, движение «За честные выборы» и многие другие.

Конечно, есть и примеры плодотворного сотрудничества гражданского общества и власти, но в основном это касается решения проблем низового уровня, местных сообществ. Власть открывает локальные возможности (территориальные, тематические, субкультурные) для проявления многообразия форм коллективной 
самоорганизации. В то же время локализация растущей социально-политической субъектности граждан и социальных групп в современном российском обществе исключительно на низовом, неформальном уровне ведет к дальнейшему отчуждению власти от общества. Все это говорит о том, что увеличение материальных, когнитивных и социальных ресурсов личности, на которые обращал внимание Р. Инглхарт, само по себе не является достаточным фактором роста гражданской активности. Не менее важным фактором является структура социально-политических возможностей, существующая в обществе в данный момент, которая осознается гражданами одновременно как условие и перспектива своего участия в общественно-политической деятельности.

В современном российском обществе сложился достаточно устойчивый комплекс публичных институтов, институциональных взаимодействий и связанных с ними социально-политических установок, воззрений и поведенческих практик, которые составляют содержание сегодняшних отношений между властью и обществом в нашей стране. Но также очевидно, что сложившийся порядок не является устойчивым и продуктивным с точки зрения долгосрочных планов развития страны. В обществе продолжает углубляться отчуждение власти и общества, растет уровень социального и территориального неравен- ства. Фактически граждане признают, что в рамках общественной самодеятельности и самоорганизации они обладают определенной свободой самовыражения, но когда речь заходит о политическом участии и тем более о перспективах влияния на принятие политических решений, то оценка возможностей резко снижается. Все это затрагивает такие важные темы, как отсутствие реального гражданского контроля, распространение коррупции, отсутствие или закрытость информации, манипулирование общественным мнением и народным волеизъявлением - словом, все то, что в конце 2011 года стало причиной массовых акций протеста.

Российское общество, хоть и медленно, но всё-таки продвигается в зону стабильного развития, умеренно позитивных настроений и легитимного отношения к существующему политическому режиму. Повседневные практики социально-политического участия, массовые акции начала 2010-х гг. и, пожалуй, еще в большей степени события, происходящие сегодня в Украине, способствуют гражданской рефлексии и росту гражданского правосознания. Правовое демократическое государство, призванное соблюдать и защищать права и свободы человека, способно утвердится лишь в обществе, основанном на социальной справедливости, высокой правовой культуре, гражданской активности и соблюдении прав всех граждан.

\section{Библиография:}

1. Инглхарт Р., Вельцель К. Модернизация, культурные изменения и демократия: Последовательность человеческого развития. М.: Новое издательство, 2011.

2. Куда ведет кризис культуры? Опыт междисциплинарных диалогов / Под общ. ред. И.М. Клямкина. М.: Новое литературное обозрение, 2011.

3. Проблемы лесных пожаров 2010 года. 28.09.2010. [Электронный ресурс]. [Офиц. сайт Аналитического центра Ю.Левады «Левада-Центр»]. URL:http://www.levada.ru/28-09-2010/problemy-lesnykh-pozharov-2010-goda (дата обращения 20.04.2014).

4. Россия, вперед! Статья Дмитрия Медведева. 10.09.2009 г. [Электронный ресурс]. [Офиц. сайт Президента PФ]. URL:http:// kremlin.ru/transcripts/5413 (дата обращения 20.03.2014 г.).

5. Almond G.A., Sidney V. The civic culture. Political attitudes and democracy in five nations. Princeton: Princeton University Press, 1963.

6. Berman M. All that is Solid Melts Into Air: The Experience of Modernity. NY: Simon and Schuster, 1983.

7. Inglehart R., Baker W.E. Modernization, cultural change, and the persistence of traditional values // American sociological review. 2000. Vol. 65. February,

8. Putnam R.D. Bowling Alone: The Collapse and Revival of American Community. NY: Simon \& Schuster, 2000.

9. Грудцына Л.Ю., Петров С.М. Власть и гражданское общество в России: взаимодействие и противо-стояние // Административное и муниципальное право. - 2012. - 1. - С. 19-29.

10. Щупленков О.В., Щупленков Н.О. Проблемы взаимодействия гражданского общества и государства в современной России // NB: Вопросы права и политики. - 2013. - 4. - C. 1-55. DOI: 10.7256/2305-9699.2013.4.585. URL: http://www.e-notabene. ru/lr/article_585.html

11. Гуляихин В.Н. Архетипы правосознания в системе правовой культуры личности // NB: Вопросы права и политики. 2014. - № 1. - C.54-74. DOI: 10.7256/2305-9699.2014.1.10486. URL: http://e-notabene.ru/lr/article_10486.html

12. Гуляихин В.Н. Структурно-функциональные особенности различных состояний правосознания человека // NB: Вопросы права и политики. - 2012. - № 2. - C.90-116. DOI: 10.7256/2305-9699.2012.2.153. URL: http://e-notabene.ru/ lr/article 153.html 
DOI: $10.7256 / 1811-9018.2015 .2 .12138$

При цитировании этой статьи сноска на dоі обязательна

\section{Право и политика $2(182) \cdot 2015$}

13. Миронова Ю.В.. Правовой нигилизм как фактор повышения эффективности законодательства // Политика и Общество. - 2013. - № 7. - C. 104-107. DOI: 10.7256/1812-8696.2013.7.2476

14. Р. П. Сипок. Современное понимание сущности активной антикриминальной позиции населения в современном государстве // Политика и Общество. - 2012. - № 9. - С. 104-107.

15. Р. П. Сипок. Значение и эффективность средств массовой коммуникации при обеспечении общественной безопасности // Национальная безопасность / nota bene. - 2012. - № 4. - С. 104-107.

16. В.Б. Власова. Русский путь от нравственности к праву // Философия и культура. - 2012. - № 7. - С. 104-107.

17. Д.Л. Кущенко. Становление правосознания в подростковом и юношеском возрасте // Психология и Психотехника. 2012. - № 3. - С. 104-107.

18. И.А. Кацапова. Социокультурное осмысление правовой реальности. // Философия и культура. - 2009. - № 8 .

19. Т. А. Шебзухова, Н. Г. Бондаренко. Морально-правовые и политические аспекты свободы в контексте принципа детерминизма // Политика и Общество. - 2011. - № 12. - С. 104-107.

20. П.С. Гуревич. Подходы к юридической антропологии. // Психология и Психотехника. - 2011. - № 6. - С. 104-107

\section{References (transliterated):}

1. Inglkhart R., Vel'tsel' K. Modernizatsiya, kul'turnye izmeneniya i demokratiya: Posledovatel'nost' chelovecheskogo razvitiya. M.: Novoe izdatel'stvo, 2011.

2. Almond G.A., Sidney V. The civic culture. Political attitudes and democracy in five nations. Princeton: Princeton University Press, 1963.

3. Berman M. All that is Solid Melts Into Air: The Experience of Modernity. NY: Simon and Schuster, 1983.

4. Inglehart R., Baker W.E. Modernization, cultural change, and the persistence of traditional values // American sociological review. 2000. Vol. 65. February,

5. Putnam R.D. Bowling Alone: The Collapse and Revival of American Community. NY: Simon \& Schuster, 2000.

6. Grudtsyna L.Yu., Petrov S.M. Vlast' i grazhdanskoe obshchestvo v Rossii: vzaimodeistvie i protivo-stoyanie // Administrativnoe i munitsipal'noe pravo. - 2012. - 1. - C. 19-29.

7. Shchuplenkov O.V., Shchuplenkov N.O. Problemy vzaimodeistviya grazhdanskogo obshchestva i gosudarstva v sovremennoi Rossii // NB: Voprosy prava i politiki. - 2013. - 4. - C. 1-55. DOI: 10.7256/2305-9699.2013.4.585. URL: http://www.e-notabene. ru/lr/article_585.html

8. Gulyaikhin V.N. Arkhetipy pravosoznaniya v sisteme pravovoi kul'tury lichnosti // NB: Voprosy prava i politiki. - 2014. № 1. - S.54-74. DOI: 10.7256/2305-9699.2014.1.10486. URL: http://e-notabene.ru/lr/article_10486.html

9. Gulyaikhin V.N. Strukturno-funktsional'nye osobennosti razlichnykh sostoyanii pravosoznaniya cheloveka // NB: Voprosy prava i politiki. - 2012. - № 2. - S.90-116. DOI: 10.7256/2305-9699.2012.2.153. URL: http://e-notabene.ru/lr/article_153.html

10. Mironova Yu.V.. Pravovoi nigilizm kak faktor povysheniya effektivnosti zakonodatel'stva // Politika i Obshchestvo. - 2013. № 7. - S. 104-107. DOI: 10.7256/1812-8696.2013.7.2476

11. R. P. Sipok. Sovremennoe ponimanie sushchnosti aktivnoi antikriminal'noi pozitsii naseleniya v sovremennom gosudarstve // Politika i Obshchestvo. - 2012. - № 9. - S. 104-107.

12. R. P. Sipok. Znachenie i effektivnost' sredstv massovoi kommunikatsii pri obespechenii obshchestvennoi bezopasnosti // Natsional'naya bezopasnost' / nota bene. - 2012. - № 4. - S. 104-107.

13. V.B. Vlasova. Russkii put' ot nravstvennosti k pravu // Filosofiya i kul’tura. - 2012. - № 7. - S. 104-107.

14. D.L. Kushchenko. Stanovlenie pravosoznaniya v podrostkovom i yunosheskom vozraste // Psikhologiya i Psikhotekhnika. - 2012. - № 3. - S. 104-107.

15. I.A. Katsapova. Sotsiokul'turnoe osmyslenie pravovoi real'nosti. // Filosofiya i kul’tura. - 2009. - № 8.

16. T. A. Shebzukhova, N. G. Bondarenko. Moral'no-pravovye i politicheskie aspekty svobody v kontekste printsipa determinizma // Politika i Obshchestvo. - 2011. - № 12. - S. 104-107.

17. P.S. Gurevich. Podkhody k yuridicheskoi antropologii. // Psikhologiya i Psikhotekhnika. - 2011. - № 6. - S. 104-107 